\title{
Dissection of voltage-gated sodium channels in developing cochlear sensory epithelia
}

\section{Dear Editor,}

Hair cells (HCs) clustered in cochlear sensory epithelia produce spontaneous spike and evoked action potentials during the developmental stage of auditory, which rely on many ion channels, such as $\mathrm{Ca}^{2+}$ channels, $\mathrm{K}^{+}$channels and $\mathrm{Na}^{+}$channels (Housley et al., 2006; Marcotti et al., 2003). As the dominant molecule acting in action potentials in most of excitable cells, $\mathrm{Na}^{+}$channels (VGSCs) were deemed to be indispensable in the spontaneous and evoked action potentials of HCs (Marcotti et al., 2003). The inward $\mathrm{Na}^{+}$currents recorded from hair cells, shorten the time to reach the action-potential threshold (Eckrich et al., 2012). However, little was known about the tissue- or developmental expression and the molecular structural information of $\mathrm{Na}^{+}$ channel subtype in hair cells, which extremely restricts the understanding of physiological mechanisms related to hearing development.

To examine whether there exist any novel sodium channel subtype in cochlear hair cells, the sensory epithelia locating in premature mouse cochlea was carefully dissected and used for the identification of VGSCs in cochlear hair cells. Three pairs of degenerate primers derived from conserved region of mammalian VGSCs (Table S2), as well as their invertebrate counterparts (from Drosophila, cockroach, housefly and mosquito), were used for detecting the homologous sequence of cochlear VGSCs. All the resultant sequences were matched to the known mammalian VGSC subtypes $\left(\mathrm{Na}_{\mathrm{v}} 1.1-1.9\right.$, data not shown), indicating that no novel sodium channel subtype could be found in cochlea. Subtype-specific primers corresponding to conserved regions of $\mathrm{Na}_{v} 1.1-1.9$ were designed and used to probe and quantify the abundance of VGSCs expressed in cochlea (Table S1). Analysis of these cDNA fragments ranging from 115 to 340 bp revealed that all the known VGSC subtypes could be detected in cochlea though in a less expression level than that of $\mathrm{Ca}_{v} 1.3$ (Fig. $1 \mathrm{~A}$ ).

Co-expression of multiple $\mathrm{Na}^{+}$channel isoforms has been described not only in neurons from the brain but also in primary sensory receptors of the mammalian cochlea. $\mathrm{Na}_{\mathrm{v}} 1.7$ has been suggested as the main carrier of $I_{\mathrm{Na}}$ in mouse inner hair cells because of the distinct biophysical and pharmacological properties (Marcotti et al., 2003). Both $\mathrm{Na}_{\mathrm{v}} 1.1$ and
$\mathrm{Na}_{\mathrm{v}} 1.6$ were identified through immunohistochemistry on cell membrane of rat hair cells, while $\mathrm{Na}_{\mathrm{v}} 1.2$ was localized to the unmyelinated efferent axons and terminals (Eckrich et al., 2012). $\mathrm{Na}_{v} 1.6$ with high expression in sensory epithelia is considered as the developmental regulator involved in the frequency of action potential activity and hair cell maturation. In this study, four sodium channels mentioned above were found with pronounced expression, providing further evidence of these subtypes in regulating action potential (Eckrich et al., 2012; Marcotti et al., 2003). Nevertheless, $\mathrm{Na}_{v} 1.4$, $\mathrm{Na}_{\mathrm{v}} 1.5, \mathrm{Na}_{\mathrm{v}} 1.8$ and $\mathrm{Na}_{\mathrm{v}} 1.9$, were found to be expressed in relatively low levels in cochlear sensory epithelia (Fig. 1A).

To obtain a clear view on the structural features of cochlear VGSCs, specific primers were designed to clone the coding sequences (CDS) of all the VGSCs identified (Table S2). The sequences of cochlear $\mathrm{Na}_{\mathrm{v}} 1.1$ and $\mathrm{Na}_{\mathrm{v}} 1.4$ were identical with that of counterparts in other mouse tissues. The other seven full-length VGSCs or structural variants comprised 5298 and 6021 bp (Genebank number: KM373687-373700), encoding for 1765 and 2006 amino acids.

According to the generally acceptable nomenclature (Goldin et al., 2000), the cochlear VGSCs mentioned above were named as $\mathrm{C}_{\mathrm{bm}} \mathrm{Na}_{\mathrm{v}} 1 . \mathrm{x}$, in which the subscript letter 'bm' indicates the originated tissue of cochlear VGSCs and '1. $x$ ' indicates the corresponded mammalian $\mathrm{Na}_{v}$ counterparts. For instance, cochlear VGSC corresponding to $\mathrm{Na}_{\mathrm{v}} 1.2$ was named $\mathrm{C}_{\mathrm{bm}} \mathrm{Na}_{\mathrm{v}}$ 1.2. Hereinafter, alternative splicing or RNAediting variants that belong to $\mathrm{C}_{\mathrm{bm}} \mathrm{Na}_{\mathrm{v}} 1.2$ were named as $\mathrm{C}_{\mathrm{bm}} \mathrm{Na}_{\mathrm{v}} 1.2 \mathrm{a}, \mathrm{C}_{\mathrm{bm}} \mathrm{Na}_{\mathrm{v}} 1.2 \mathrm{~b} \ldots$, respectively. When mapping these sequences of $\mathrm{C}_{\mathrm{bm}} \mathrm{Na}_{\mathrm{v}} 1 . x$ to the mouse genome, it was found that $\mathrm{C}_{\mathrm{bm}} \mathrm{Na}_{\mathrm{v}} 1 . \mathrm{x}$ were subjected to diverse point mutations, fragment insertions and deletions brought by the alternative splicing and RNA-editing events, most of which sit in functionally significant regions (Fig. 1B). All the editing sites and alternative splicing sites were double checked by pyrosequencing to remove any interference of RT-PCR errors. The sites location and nucleotide substitution patterns of all the alternative splicing and RNA-editing variants were shown in Table 1.

Two variants of $\mathrm{C}_{\mathrm{bm}} \mathrm{Na}_{\mathrm{v}} 1.2$ differed by a single exon 6 exhibited the same alternative splicing site (Fig. 1C and 1D), which maybe resulting in functional enhancement as 


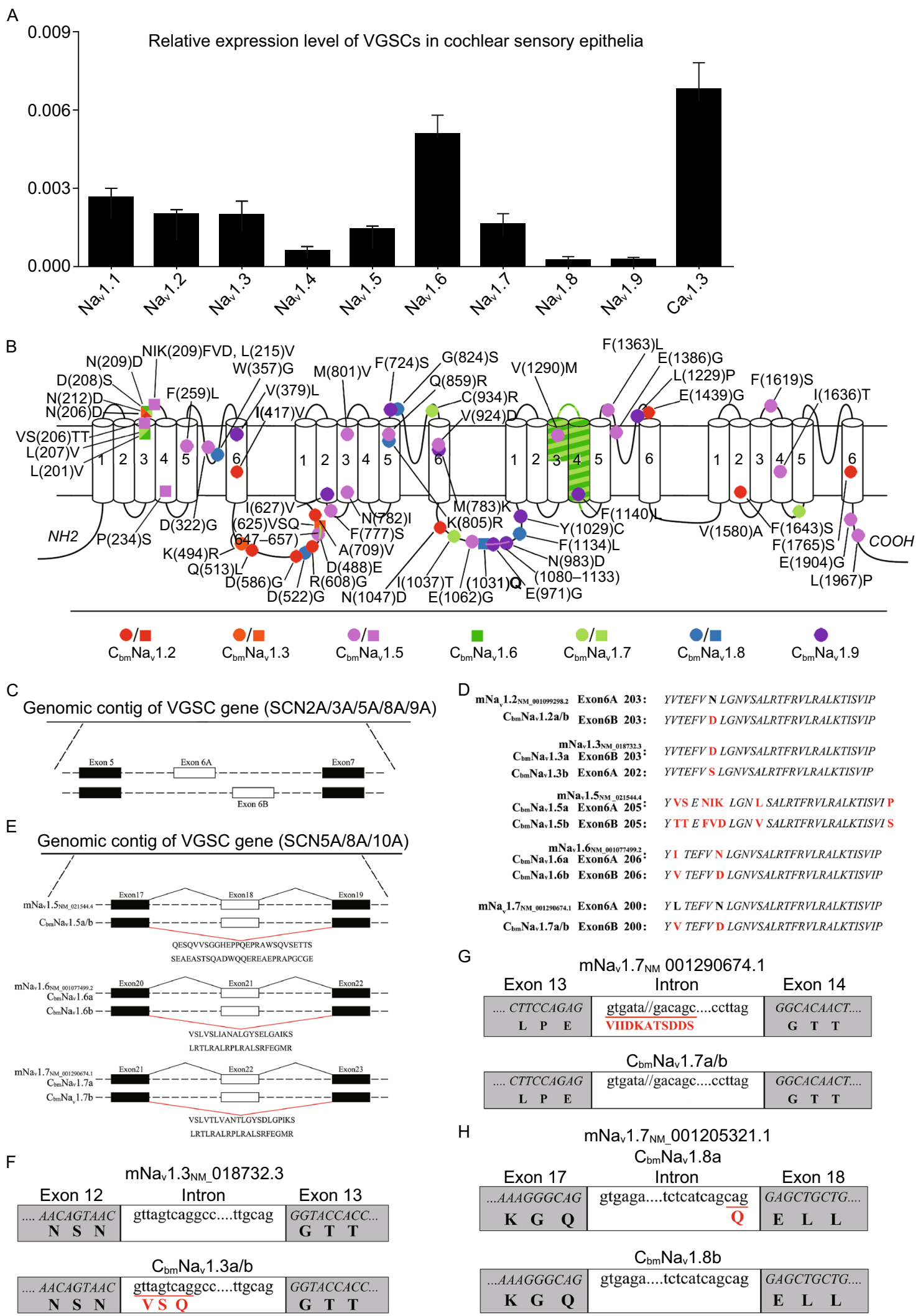


Figure 1. Molecular characteristics of sodium channels expressed in cochlear sensory epithelia. (A) Quantitative analysis of nine subtypes of sodium channels expressed in cochlear sensory epithelia. The mRNA encoding for TTX-R Na channels $\left(\mathrm{mNa}_{\mathrm{v}} 1.5, \mathrm{mNa}_{\mathrm{v}} 1.8\right.$ and $\left.\mathrm{mNa}_{\mathrm{v}} 1.9\right)$ were detected of lower expression level, the mRNA copy numbers of TTX-S Nav channels were shown at high level. (B) The schematic diagram of the sodium channel topology showed RNA editing and alternative splicing sites of $\mathrm{C}_{\mathrm{bm}} \mathrm{Na}_{\mathrm{v}} \mathrm{s}$. RNA editing sites were illustrated with circles icon; and alternative splicing sites were highlighted with square icon. See Table 1 for details on these mutations. (C-H) Alternative splicing events occured in cochlear sodium channels.

observed in $\mathrm{hNa}_{\mathrm{v}}$ 1.2adu (Xu et al., 2007). Likewise, cochlear hair cells expressing alternatively splicing variant of $\mathrm{C}_{\mathrm{bm}} \mathrm{Na}_{\mathrm{v}} 1.2$ may display more excitable ability. R608G, A709V, Q513L and D586G identified in $\mathrm{C}_{\mathrm{bm}} \mathrm{Na}_{\mathrm{v}} 1.2$ locating at intracellular loop between DI and DII were potentially adjacent to the phosphorylation sites may greatly influence the channel activity (Chahine and O'Leary, 2014). RNAediting sites 1417V, E1439G and F1765S were located in extracellular loop between $\mathrm{S} 5$ and $\mathrm{S} 6$ of $\mathrm{C}_{\mathrm{bm}} \mathrm{Na}_{\mathrm{v}} 1.2$, relating to ionic permeability and selectivity (Fig. S1).

$\mathrm{Na}_{\mathrm{v}} 1.3$ is mainly expressed in CNS during the early development stage (Hains et al., 2003). In $\mathrm{rNa}_{\mathrm{v}} 1.3$ or $\mathrm{hNa}_{\mathrm{v}} 1.3$, extensive alternative splicing sites, such as $12 \mathrm{v} 1$, $12 \mathrm{v} 2$ and $12 \mathrm{v} 3$ (rat), as well as $12 \mathrm{v} 1,12 \mathrm{v} 2,12 \mathrm{v} 3$ and $12 \mathrm{v} 4$ (human) in DI-II intracellular loop were identified to be important for channel kinetics (Thimmapaya et al., 2005). Alternative splicing site of $12 \mathrm{v} 2$ was also detected in $\mathrm{C}_{\mathrm{bm}} \mathrm{Na}_{\mathrm{v}} 1.3$ (Fig. 1F). A missense mutation, K494R, was found in intracellular loop between $\mathrm{DI}$ and $\mathrm{DIl}$ in both variant $\mathrm{C}_{\mathrm{bm}} \mathrm{Na}_{\mathrm{v}} 1.3 \mathrm{a}$ and $\mathrm{C}_{\mathrm{bm}} \mathrm{Na}_{\mathrm{v}} 1.3 \mathrm{~b}$. Similar to $\mathrm{rNa}_{\mathrm{v}} 1.2$, a missense mutation D208S of $\mathrm{C}_{\mathrm{bm}} \mathrm{Na}_{\mathrm{v}} 1.3$ at extracellular loop between $\mathrm{S} 3$ and $\mathrm{S} 4$ of the $\mathrm{DI}$ was caused by alternative splicing on Exon $6 \mathrm{~A}$ or Exon $6 \mathrm{~B}$ (Fig. $1 \mathrm{C}$ and 1D). All of these mutations might have substantial impact on phosphorylation and gating properties of the channel.

To date, seven alternative splicing variants of $\mathrm{Na}_{v} 1.5$ including $\mathrm{Na}_{\mathrm{v}} 1.5 \mathrm{a}$ (exon 18 deletion), $\mathrm{Na}_{\mathrm{v}} 1.5 \mathrm{~b}$ (exon 17 and

Table 1. Common and unique amino acid changes in fifteen $\mathrm{C}_{\mathrm{bm}} \mathrm{Na}_{\mathrm{v}}$ variants

\begin{tabular}{|c|c|c|c|c|c|c|c|}
\hline & $\mathrm{C}_{\mathrm{bm}} \mathrm{Na}_{\mathrm{v}} 1.2$ & $\mathrm{C}_{\mathrm{bm}} \mathrm{Na}_{\mathrm{v}} 1.3$ & $\mathrm{C}_{\mathrm{bm}} \mathrm{Na}_{\mathrm{v}} 1.5$ & $\mathrm{C}_{\mathrm{bm}} \mathrm{Na}_{\mathrm{v}} 1.6$ & $\mathrm{C}_{\mathrm{bm}} \mathrm{Na}_{\mathrm{v}} 1.7$ & $\mathrm{C}_{\mathrm{bm}} \mathrm{Na}_{\mathrm{v}} 1.8$ & $\mathrm{C}_{\mathrm{bm}} \mathrm{Na}_{\mathrm{v}} 1.9$ \\
\hline$t-a$ & & & V924D & & & & $\mathrm{M} 83 \mathrm{~K}^{\mathrm{abc}}$ \\
\hline$t-g$ & & & $\mathrm{D} 488 \mathrm{E}^{\mathrm{b}}$ & & & W357G ${ }^{a b}$ & \\
\hline$t-c$ & $\begin{array}{l}\text { V1580A } A^{a} \\
F 1765 S^{b}\end{array}$ & & $\begin{array}{l}\text { F259L }{ }^{a} \\
\text { F777 }^{a} \\
\text { F1363L } \\
\text { I1636T }^{\mathrm{a}} \\
\text { F1619S } \\
\text { L1967P }^{\mathrm{b}}\end{array}$ & & $\begin{array}{l}\text { C934R } \\
\text { I1037 } \\
\text { F1643S } \\
\text { ab }\end{array}$ & $\mathrm{F} 1134 \mathrm{~L}^{\mathrm{ab}}$ & $\begin{array}{l}\text { F724S } \text { abc }^{\text {F1140L }} \\
\text { L1229P }^{\mathrm{b}}\end{array}$ \\
\hline$a-g$ & $\begin{array}{l}1417 V^{b} \\
D 586 G^{b} \\
R 608 G^{a} \\
N 1047 D^{b} \\
E 1439 G^{b}\end{array}$ & $\mathrm{~K} 494 \mathrm{R}^{\mathrm{a}}$ & $\begin{array}{l}\text { D322G } \\
\text { Q859R }^{\mathrm{a}} \\
\text { M801V }^{\mathrm{b}} \\
\mathrm{E} 1062 \mathrm{G}^{\mathrm{b}} \\
\mathrm{E} 1386 \mathrm{G}^{\mathrm{b}} \\
\mathrm{E} 1904 \mathrm{G}^{\mathrm{b}}\end{array}$ & & & $\begin{array}{l}\text { D522G }{ }^{\text {ab }} \\
\text { K805R }\end{array}$ & $\begin{array}{l}\text { I627V } \mathrm{V}^{\mathrm{abc}} \\
\mathrm{E} 971 \mathrm{G}^{\mathrm{c}} \\
\mathrm{N} 93 \mathrm{D}^{\mathrm{c}} \\
\mathrm{Y} 1029 \mathrm{C}^{\mathrm{b}}\end{array}$ \\
\hline$a-t$ & Q513 $L^{b}$ & & $\mathrm{~N} 782 \mathrm{I}^{\mathrm{a}}$ & & & & \\
\hline$g-a$ & & & $\mathrm{~V} 1290 \mathrm{M}^{\mathrm{b}}$ & & & $\mathrm{G} 824 \mathrm{~S}^{\mathrm{ab}}$ & \\
\hline$g-t$ & & & & & & & V379L ${ }^{a b c}$ \\
\hline$c-t$ & A709V ${ }^{a}$ & & & & & & \\
\hline Substitution & $\mathrm{N} 209 \mathrm{D}^{\mathrm{ab}}$ & $\mathrm{D} 208 \mathrm{~S}^{\mathrm{b}}$ & $\begin{array}{l}\text { VS206TT } \\
\text { NIK209 } \\
\text { FVD }^{\mathrm{b}} \\
\text { L215V }^{\mathrm{b}} \\
\text { P234S }^{\mathrm{b}}\end{array}$ & $\begin{array}{l}\mathrm{I} 207 \mathrm{~V}^{\mathrm{b}} \\
\mathrm{N} 212 \mathrm{D}^{\mathrm{b}}\end{array}$ & $\begin{array}{l}\text { L201V }^{\text {ab }} \\
\text { N206D }\end{array}$ & & \\
\hline Deletion & & & $1080-1133^{\mathrm{ab}}$ & $1272-1312^{b}$ & $\begin{array}{l}1266-1306^{b} \\
647-657^{\mathrm{b}}\end{array}$ & & \\
\hline Insertion & & $625 V_{S Q}^{a b}$ & & & & $1031 Q^{b}$ & \\
\hline
\end{tabular}

Amino acid sequences of these variants ( $a, b$ and $c$ represent different variant of each VGSC subtype) were compared with the genome sequence of corresponding subtypes. Nucleotide bases of RNA editing events that correspond to these in the mNa $\mathrm{m}_{\mathrm{v}}$ genomic sequence were in bold. Alternative splicing events included exons mutual repulsion resulting amino acid changes, exons kipping resulting amino acid deletion, alternative $3^{\prime}$ splicing and alternatives $5^{\prime}$ splicing resulting amino acid deletion and insertion. 
exon 18 deletion), $\mathrm{Na}_{\mathrm{v}} 1.5 \mathrm{c}$ (CAG inclusive variant), $\mathrm{Na}_{\mathrm{v}} 1.5 \mathrm{~d}$ (exon 17 splicing), $\mathrm{Na}_{\mathrm{v}} 1.5 \mathrm{e}$ (exon 6 splicing), $\mathrm{Na}_{\mathrm{v}} 1.5 \mathrm{f}$ (exon 24 deletion) and C-terminal splice variants, have been reported (Schroeter et al., 2010). According to the splicing pattern, distribution and expressive proportion, these variants showed diversities in different species and different tissues of same species. Of all the VGSC subtypes found in mouse cochlear sensory epithelia, $\mathrm{C}_{\mathrm{bm}} \mathrm{Na}_{\mathrm{v}} 1.5$ was subjected to the most intensive RNA-editing modification, among which T-to-C and A-to-G were the two common nucleotide substitution patterns, containing six editing sites each. Surprisingly, $\mathrm{C}_{\mathrm{bm}} \mathrm{Na}_{\mathrm{v}} 1.5$ was substantially modified by alternative splicing as well, resulting in two alternative splicing variants having significant deletion at functionally important regions of the channel: to have seven amino acid residues substitution at DI S3-S4 extracellular loop were found in $\mathrm{C}_{\mathrm{bm}} \mathrm{Na}_{\mathrm{v}} 1.5 \mathrm{~b}$. In addition, $\mathrm{C}_{\mathrm{bm}} \mathrm{Na}_{\mathrm{v}} 1.5 \mathrm{a}$ and $\mathrm{C}_{\mathrm{bm}} \mathrm{Na}_{\mathrm{v}} 1.5 \mathrm{~b}$ lost the entire exon 18 at DI-DIII intracellular loop which contained 54 amino acid residues (Fig. 1E, Table 1). Notably, exon 18 deletion, encoding for 53 amino acids at the DII-DIII linker (residues 1078-1130 in $\mathrm{hNa}_{\mathrm{v}} 1.5$ ), was the first reported splice variant in the cardiac $\mathrm{Na}^{+}$channel. This splicing variant showed a pronounced species-specific expression pattern in mammals (Blechschmidt et al., 2008).

$\mathrm{Na}_{v} 1.6$ is widely expressed in both PNS and CNS (Caldwell et al., 2000). A variant of $h \mathrm{Na}_{\mathrm{v}} 1.6$ lost a part of $\mathrm{S} 3$ and the whole transmembrane S4 at DIII (Zubovic et al., 2012a). Alternative splicing sites previously found in $\mathrm{rNa}_{\mathrm{v}} 1.6$

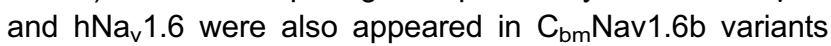
which appeared as a loss of exon 21 , taking away partial sequence of DIIIS3 and the entire DIIIS4 (Fig. 1E). Our finding identified the same deletion in $\mathrm{C}_{\mathrm{bm}} \mathrm{Na}_{\mathrm{v}} 1.6 \mathrm{~b}$ of mouse cochlea (Fig. 1E). Deletion of exon 21 caused the loss of voltage sensor S4, it may be a "fail-safe" mechanism that produces a non-functional truncated protein (Plummer et al., 1997).

Alternative splicing variants of $\mathrm{Na}_{\mathrm{v}} 1.7$ were found in dorsal root ganglia (DRG) neurons under neuropathic pain conditions of rats (Dib-Hajj et al., 2013). In this study, $\mathrm{C}_{\mathrm{bm}} \mathrm{Na}_{\mathrm{v}} 1.7 \mathrm{a}$ and $\mathrm{C}_{\mathrm{bm}} \mathrm{Na}_{\mathrm{v}} 1.7 \mathrm{~b}$ were characterized by the existence of exon $6 \mathrm{~B}$, differing at two amino acids $(201 \mathrm{~V}$, 206D) in the D1/S3-S4 linker comparing to $\mathrm{mNa}_{\mathrm{v}} 1.7$ (201L, 206N) (Fig. 1C and 1D). Previous study revealed that the variant containing exon $6 \mathrm{~B}$ had slower kinetics of inactivation for negative potentials than that of the variant containing exon 6A (Chatelier et al., 2008; Jarecki et al., 2009). Meanwhile, exon 22 deletion was first observed in $\mathrm{C}_{\mathrm{bm}} \mathrm{Na}_{\mathrm{v}} 1.7 \mathrm{~b}$ which was lacking partial sequence of DIIIS3 and the entire DIIIS4 (Fig. 1E), suggested that the truncated protein maybe bear a similar protection mechanism to Nav1.6 (Plummer et al., 1997; Zubovic et al., 2012b).

Electronic supplementary material The online version of this article (doi:10.1007/s13238-015-0157-1) contains supplementary material, which is available to authorized users.
For $\mathrm{C}_{\mathrm{bm}} \mathrm{Na}_{\mathrm{v}} 1.8$, it was found five RNA-editing sites located at the DI/DII pore region and intracellular loops. Nine novel RNA-editing sites were identified in two $\mathrm{C}_{\mathrm{bm}} \mathrm{Nav1.9}$ variant, eight of which were caused by the nucleotide changes of adenine to guanine (Table 1). The alternative splicing event caused a deletion of Glu at position 1031 of $\mathrm{C}_{\mathrm{bm}} \mathrm{Na}_{\mathrm{v}} 1.8 \mathrm{~b}($ Fig. $1 \mathrm{H})$. Few cases have been approached as for the functional consequences of these mutations. Although several mutation sites in $\mathrm{Na}_{\mathrm{v}} 1.8$ and $\mathrm{Na}_{\mathrm{v}} 1.9$ variants were identified, whether these mutations may diversify the function of channels will still need further researches.

Groundbreakingly, all known subtypes of sodium channels were identified in mouse cochlear sensory epithelia before hearing onset, strongly indicating the indispensible role in hearing development and formation. Moreover, some structural variations of $\mathrm{C}_{\mathrm{bm}} \mathrm{Na}_{\mathrm{v}}$ were found, possibly endowing distinct functions in order to adapt to the physiologically distinct properties for the cochlear VGSCs. This work lays a foundation for further studies to understand the roles of diverse $\mathrm{C}_{\mathrm{bm}} \mathrm{Na}_{\mathrm{v}}$ variants in shaping action potentials in cochlea and regulating hearing development.

\section{FOOTNOTES}

The authors gratefully acknowledge Prof. Lin Chen for his interests in this study and providing valuable help with cochlear microdissection. This study was supported by the National Basic Research Program (973 Program) (No. 2010CB529806), partially by grants from National Natural Science Foundation of China (Grant No. 31171064) and Key Research Program of Science and Technology Commissions of Shanghai Municipality (11JC1404300, 13DJ1 400300).

You Zhou, Fang-Hao Fang, Zhi-Rui Liu and Yong-Hua Ji declare that they have no conflict of interest. All institutional and national guidelines for the care and use of laboratory animals were followed.

\section{You Zhou, Fang-Hao Fang, Zhi-Rui Liu, Yong-Hua $\mathrm{Ji}^{\bowtie}$}

Laboratory of Neuropharmacology and Neurotoxicology, Shanghai University, Shanghai 200436, China

$\triangle$ Correspondence: yhji@staff.shu.edu.cn (Y.-H. Ji)

\section{OPEN ACCESS}

This article is distributed under the terms of the Creative Commons Attribution 4.0 International License (http://creativecommons.org/ licenses/by/4.0/), which permits unrestricted use, distribution, and reproduction in any medium, provided you give appropriate credit to the original author(s) and the source, provide a link to the Creative Commons license, and indicate if changes were made.

\section{REFERENCES}

Blechschmidt S, Haufe V, Benndorf K, Zimmer T (2008) Voltagegated $\mathrm{Na}+$ channel transcript patterns in the mammalian heart are species-dependent. Prog Biophys Mol Biol 98:309-318 
Caldwell JH, Schaller KL, Lasher RS, Peles E, Levinson SR (2000) Sodium channel $\mathrm{Na}(\mathrm{v}) 1.6$ is localized at nodes of Ranvier, dendrites, and synapses. Proc Natl Acad Sci USA 97:5616-5620

Chahine M, O'Leary ME (2014) Regulation/modulation of sensory neuron sodium channels. Handb Exp Pharmacol 221:111-135

Chatelier A, Dahllund L, Eriksson A, Krupp J, Chahine M (2008) Biophysical properties of human Na v1.7 splice variants and their regulation by protein kinase A. J Neurophysiol 99:2241-2250

Dib-Hajj SD, Yang Y, Black JA, Waxman SG (2013) The Na(V)1.7 sodium channel: from molecule to man. Nat Rev Neurosci 14:4962

Eckrich T, Varakina K, Johnson SL, Franz C, Singer W, Kuhn S, Knipper M, Holley MC, Marcotti W (2012) Development and function of the voltage-gated sodium current in immature mammalian cochlear inner hair cells. PLoS One 7:e45732

Goldin AL, Barchi RL, Caldwell JH, Hofmann F, Howe JR, Hunter JC, Kallen RG, Mandel G, Meisler MH, Netter YB et al (2000) Nomenclature of voltage-gated sodium channels. Neuron 28:365-368

Hains BC, Klein JP, Saab CY, Craner MJ, Black JA, Waxman SG (2003) Upregulation of sodium channel Nav1.3 and functional involvement in neuronal hyperexcitability associated with central neuropathic pain after spinal cord injury. J Neurosci 23:88818892

Housley GD, Marcotti W, Navaratnam D, Yamoah EN (2006) Hair cells-beyond the transducer. J Membr Biol 209:89-118

Jarecki BW, Sheets PL, Xiao YC, Jackson JO, Cummins TR (2009) Alternative splicing of $\mathrm{Na}(\mathrm{V}) 1.7$ exon 5 increases the impact of the painful PEPD mutant channel I1461T. Channels 3:259-267
Marcotti W, Johnson SL, Rusch A, Kros CJ (2003) Sodium and calcium currents shape action potentials in immature mouse inner hair cells. J Physiol 552:743-761

Plummer NW, McBurney MW, Meisler MH (1997) Alternative splicing of the sodium channel SCN8A predicts a truncated two-domain protein in fetal brain and non-neuronal cells. J Biol Chem 272:24008-24015

Schroeter A, Walzik S, Blechschmidt S, Haufe V, Benndorf K, Zimmer T (2010) Structure and function of splice variants of the cardiac voltage-gated sodium channel $\mathrm{Na}(\mathrm{v}) 1.5$. J Mol Cell Cardiol 49:16-24

Thimmapaya R, Neelands T, Niforatos W, Davis-Taber RA, Choi W, Putman CB, Kroeger PE, Packer J, Gopalakrishnan M, Faltynek $\mathrm{CR}$ et al (2005) Distribution and functional characterization of human Nav1.3 splice variants. Eur J Neurosci 22:1-9

Xu R, Thomas EA, Jenkins M, Gazina EV, Chiu C, Heron SE, Mulley JC, Scheffer IE, Berkovic SF, Petrou S (2007) A childhood epilepsy mutation reveals a role for developmentally regulated splicing of a sodium channel. Mol Cell Neurosci 35:292-301

Zubovic L, Baralle M, Baralle FE (2012a) Mutually exclusive splicing regulates the Na-v 1.6 sodium channel function through a combinatorial mechanism that involves three distinct splicing regulatory elements and their ligands. Nucleic Acids Res 40:6255-6269

Zubovic L, Baralle M, Baralle FE (2012b) Mutually exclusive splicing regulates the Nav 1.6 sodium channel function through a combinatorial mechanism that involves three distinct splicing regulatory elements and their ligands. Nucleic Acids Res 40:6255-6269 